\title{
CSACl position statement: transition recommendations on existing epinephrine autoinjectors
}

\author{
Lucy Dong Xuan Li ${ }^{1}$, Elissa M. Abrams², Elana Lavine ${ }^{3,4}$, Kyla Hildebrand $^{5}$ and Douglas Paul Mack ${ }^{6,7^{*}}$ (D)
}

\begin{abstract}
Epinephrine is the first line treatment for anaphylaxis, an acute potentially life-threatening allergic reaction. It is typically administered intramuscularly in the anterolateral thigh at a dose of $0.01 \mathrm{mg} / \mathrm{kg}$ of 1:1000 (1 mg/ml) solution to a maximum initial dose of $0.5 \mathrm{mg}$. Currently in Canada, epinephrine autoinjectors (EAl) are available in three doses, $0.15 \mathrm{mg}, 0.30 \mathrm{mg}$, and $0.50 \mathrm{mg}$. There are currently no published studies comparing $0.3 \mathrm{mg}$ and $0.5 \mathrm{mg}$ EAls in the paediatric or adult populations to compare clinical effectiveness. However, as weight increases above $30 \mathrm{~kg}$, the percentage of the recommended $0.01 \mathrm{mg} / \mathrm{kg}$ epinephrine dose from an existing $0.3 \mathrm{mg}$ EAl decreases resulting in potential underdosing. As such, The Canadian Society of Allergy and Immunology (CSACl) recommends that for those who weigh $\geq 45 \mathrm{~kg}$, physicians could consider prescribing the $0.50 \mathrm{mg}$ EAl based on shared decision making with patients.
\end{abstract}

Keywords: Epinephrine, Anaphylaxis, CSACl position statement, 0.5 mg epinephrine autoinjector

\section{Background}

\section{Anaphylaxis and the importance of epinephrine}

Anaphylaxis is an acute potentially life-threatening allergic reaction with a lifetime prevalence between 1.6 and $5.1 \%$ [1]. In children, food allergy is a leading cause of anaphylaxis, while medications and insect venom are more common causes in the adult population [2]. While definitions vary, anaphylaxis is a clinical diagnosis and is characterized as a severe reaction that may involve a wide range of organ systems and is typically rapid in onset. The World Allergy Organization (WAO) Anaphylaxis Committee in 2020 modified the existing National Institute of Allergy and Infectious Diseases and the Food Allergy and Anaphylaxis Network (NIAID/FAAN) criteria with an aim to simplify the criteria by combining the first two NIAID/FAAN criteria and modifying the

\footnotetext{
*Correspondence: dougpmack@gmail.com

${ }^{7}$ Halton Pediatric Allergy, Burlington, ON, Canada

Full list of author information is available at the end of the article
}

third (Table 1) $[3,4]$. While anaphylaxis may be lifethreatening, fatal anaphylaxis is a rare occurrence and has been estimated to range from 0.064 to 0.099 deaths per 100,000 population per annum in the UK, US, and Australia [5].

The first line treatment for anaphylaxis is epinephrine which is typically administered intramuscularly (IM) in the anterolateral thigh at a dose of $0.01 \mathrm{mg} / \mathrm{kg}$ of $1: 1000$ $(1 \mathrm{mg} / \mathrm{ml})$ solution to a maximum initial dose of $0.5 \mathrm{mg}$ [2]. The dose recommendations for anaphylaxis have been based on clinical experience and extrapolated from uses of epinephrine in other conditions and limited data exist to determine the precise dose for all patients. Epinephrine functions via its effects on alpha1-adrenergic, beta-1-adrenergic, and beta-2-adrenergic receptors to decrease airway edema, increase peripheral vascular resistance via vasoconstriction, induce cardiac inotropic and chronotropic effects, stimulate bronchodilation, and decrease mediator release [2]. original author(s) and the source, provide a link to the Creative Commons licence, and indicate if changes were made. The images or other third party material in this article are included in the article's Creative Commons licence, unless indicated otherwise in a credit line to the material. If material is not included in the article's Creative Commons licence and your intended use is not permitted by statutory regulation or exceeds the permitted use, you will need to obtain permission directly from the copyright holder. To view a copy of this licence, visit http://creativecommons.org/licenses/by/4.0/. The Creative Commons Public Domain Dedication waiver (http://creativeco mmons.org/publicdomain/zero/1.0/) applies to the data made available in this article, unless otherwise stated in a credit line to the data. 
Table 1 Clinical criteria for diagnosing anaphylaxis

\begin{tabular}{|c|c|}
\hline $\begin{array}{l}\text { WAO } 2020 \text { Criteria [3]: anaphylaxis is likely when any one of the following } \\
2 \text { criteria are fulfilled: }\end{array}$ & $\begin{array}{l}\text { NIAID/FAAN Criteria [4]: fulfilling any } 1 \text { of the following } 3 \text { criteria } \\
\text { indicates anaphylaxis is highly likely }\end{array}$ \\
\hline Criterion 1: & Criterion 1: \\
\hline $\begin{array}{l}\text { Acute onset of an illness (minutes to several hours) with simultaneous } \\
\text { involvement of the skin, mucosal tissue, or both (ex: generalized hives, pruritus } \\
\text { or flushing, swollen lips-tongue-uvula) and at least one of the following: }\end{array}$ & $\begin{array}{l}\text { Sudden onset of an illness (minutes to several hours), with } \\
\text { involvement of the skin, mucosal tissue, or both (ex: generalized } \\
\text { hives, itching or flushing, swollen lips-tongue-uvula) and at least one } \\
\text { of the following: }\end{array}$ \\
\hline $\begin{array}{l}\text { (i) Respiratory compromise (ex: dyspnea, wheeze-bronchospasm, stridor, } \\
\text { reduced peak expiratory flow, hypoxemia) }\end{array}$ & $\begin{array}{l}\text { (i) Sudden respiratory symptoms and signs (ex: shortness of } \\
\text { breath, wheeze, cough, stridor, hypoxemia) }\end{array}$ \\
\hline $\begin{array}{l}\text { (ii) Reduced BP or associated symptoms of end-organ dysfunction (ex: } \\
\text { hypotonia, syncope, incontinence) }\end{array}$ & $\begin{array}{l}\text { (ii) Sudden reduced BP or symptoms of end-organ dysfunction } \\
\text { (ex: hypotonia, incontinence) }\end{array}$ \\
\hline $\begin{array}{l}\text { (iii) Severe gastrointestinal symptoms (ex: severe crampy abdominal pain, } \\
\text { repetitive vomiting), especially after exposure to non-food allergens }\end{array}$ & Criterion 2: \\
\hline Criterion 2: & $\begin{array}{l}\text { Two or more of the following that occur suddenly after exposure to a } \\
\text { likely allergen or other trigger for that patient (minutes to hours) }\end{array}$ \\
\hline \multirow{8}{*}{$\begin{array}{l}\text { Acute onset of hypotension or bronchospasm or laryngeal involvement after } \\
\text { exposure to a known or highly probably allergen for that patient (minutes to } \\
\text { several hours), even in the absence of typical skin involvement }\end{array}$} & $\begin{array}{l}\text { (i) Sudden skin or mucosal symptoms and signs (ex: generalized } \\
\text { hives, itch-flush, swollen lips-tongue-uvula) }\end{array}$ \\
\hline & $\begin{array}{l}\text { (ii) Sudden respiratory symptoms and signs (ex: shortness of } \\
\text { breath, wheeze, cough, stridor, hypoxemia) }\end{array}$ \\
\hline & $\begin{array}{l}\text { (iii) Sudden reduced BP or symptoms of end-organ dysfunction } \\
\text { (ex: hypotonia, incontinence) }\end{array}$ \\
\hline & $\begin{array}{l}\text { Sudden gastrointestinal symptoms (ex: cramping abdominal pain, } \\
\text { vomiting) }\end{array}$ \\
\hline & Criterion 3: \\
\hline & $\begin{array}{l}\text { Reduced blood pressure (BP) after exposure to a known allergen for } \\
\text { that patient (minutes to hours) }\end{array}$ \\
\hline & $\begin{array}{l}\text { (i) Infants and children: low systolic BP (age specific) or greater } \\
\text { than } 30 \% \text { decrease in systolic BP }\end{array}$ \\
\hline & $\begin{array}{l}\text { (ii) Adults: systolic BP of less than } 90 \text { mm Hg or greater than 30\% } \\
\text { decrease from that person's baseline }\end{array}$ \\
\hline
\end{tabular}

While syringe and ampule administration may be reasonable in hospitals and clinics, patients and/or caregivers do not typically have access to these supplies and this method may increase risks of inaccurate dosing and delays in administration, even amongst health care professionals [6]. Until recently in Canada, epinephrine autoinjectors (EAI) were only available in fixed doses of $0.15 \mathrm{mg}$ and $0.3 \mathrm{mg}$. Product monographs for such autoinjectors advise the usage of $0.15 \mathrm{mg}$ autoinjectors for individuals weighing $15-30 \mathrm{~kg}$ and the $0.3 \mathrm{mg}$ autoinjectors for those weighing $\geq 30 \mathrm{~kg}$. However, these doses potentially result in suboptimal dosing in patients not weighing exactly 15 or $30 \mathrm{~kg}$.

Currently, various medical professional organizations recommend that appropriate dosing of EAIs based on weight should allow for flexibility at the highest and lowest weights in the ranges suggested by product monographs. The CSACI has previously published a guideline suggesting that infants $<15 \mathrm{~kg}$ should be prescribed the $0.15 \mathrm{mg}$ dose of autoinjector, despite its published monograph [7]. Similarly, other recommendations have suggested that patients weighing $<25 \mathrm{~kg}$ should use the $0.15 \mathrm{mg}$ dose and those $\geq 25 \mathrm{~kg}$ should switch to the $0.3 \mathrm{mg}$ dose $[7,8]$. In fact, Australian guidelines suggest that this dose transition occur even lower, at $20 \mathrm{~kg}$ [9]. In October 2020, an EAI became available in Canada for the first time with a dose of $0.5 \mathrm{mg}$. Although the product monograph for that device advises the $0.5 \mathrm{mg}$ dose for individuals over $60 \mathrm{~kg}$, no guidelines to date have outlined when a prescriber should consider transitioning to the $0.5 \mathrm{mg}$ dose in the paediatric population. It has been suggested that a $40 \mathrm{~kg}$ individual would receive only $75 \%$ of the ideal dose with a $0.3 \mathrm{mg}$ EAI, using the weight-based per kilogram dose indicated above [10].

There are currently no published studies comparing $0.3 \mathrm{mg}$ and $0.5 \mathrm{mg}$ EAIs in the paediatric or adult populations to compare clinical effectiveness. Pharmacokinetically, the plasma concentration of epinephrine peaks at $5 \mathrm{~min}$ and $30-50 \mathrm{~min}$ after injection $[11,12]$. Turner et al. demonstrated that increasing the injected dose from $0.3 \mathrm{mg}$ to $0.5 \mathrm{mg}$ 
while using an adequate needle length will increase the plasma level of epinephrine [13]. The dose recommendation for treatment of anaphylaxis with $0.01 \mathrm{mg} / \mathrm{kg}$ (maximum $0.5 \mathrm{mg}$ ) of $1 \mathrm{mg} / \mathrm{ml}$ epinephrine solution given IM has been based on clinical experience but has also been extrapolated from literature supporting the doses of epinephrine used in other conditions.

Needle length of the various EAIs have also been studied and appears to be a potential concern when administering the $0.15 \mathrm{mg}$ autoinjectors into patients weighing less than $15 \mathrm{~kg}$. Studies have shown that in infants who are $<15 \mathrm{~kg}$, the needle length could potentially hit the bone in $29 \%$ to $43 \%$ of cases $[14,15]$. In adults, the anterolateral aspect of the thigh is higher in women than men and as such, the $0.3 \mathrm{mg}$ device may not reach the muscle in many women [16-18]. With this in mind, the new $0.5 \mathrm{mg}$ EAI available in Canada has a needle length of $23 \mathrm{~mm}$ which is longer than the existing $0.15 \mathrm{mg}$ and $0.30 \mathrm{mg}$ EAIs available.

Clinically, it has been suggested that individuals who have a larger body habitus should carry the $0.5 \mathrm{mg}$ epinephrine autoinjector. However, to date, there have been no studies comparing epinephrine levels after epinephrine autoinjector use by obese vs non obese patients. In one study involving 261 children and 60 adults with anaphylaxis, $22 \%$ subjects with obesity did not need repeat dosing of epinephrine more than nonobese patients suggesting that pre-existing epinephrine autoinjectors can work well in obese patients [19].

This position statement will address a number of questions regarding epinephrine prescribing and administration for the paediatric population at risk of anaphylaxis, based on the EAIs currently available in Canada.

\section{What products are available?}

Currently in Canada, there are three doses for EAIs$0.15 \mathrm{mg}, 0.30 \mathrm{mg}$, and $0.50 \mathrm{mg}$ (Table 2).

Given the lack of other available EAI doses, product monographs for the existing EAIs are conservative in that, at certain transition weights, significant underdosing could theoretically occur when compared to the weight-based per kilogram doses indicated above.

Existing guidelines and position statements have addressed the issues concerning limited pre-fixed EAI doses and dose transitions.

\section{Are there risks associated with underdosing epinephrine?}

Despite the current, internationally accepted recommendation of administering $0.01 \mathrm{mg} / \mathrm{kg}$ of epinephrine to treat anaphylaxis, it is presently impossible to administer that exact dose to a child weighing between 15 and $30 \mathrm{~kg}$ with existing 0.15 and $0.3 \mathrm{mg}$ EAIs. For example, an average 7 year old child who weighs $22.5 \mathrm{~kg}$, administered an EAI of $0.15 \mathrm{mg}$, receives a $33 \%$ underdose; administering an EAI of $0.3 \mathrm{mg}$ delivers a potential $33 \%$ overdose [20]. Similarly, using a $0.3 \mathrm{mg}$ EAI for a $50 \mathrm{~kg}$ adult would result in a $40 \%$ underdose. As such, physicians face a common dilemma of choosing whether to potentially under- or over- dose a patient with existing EAIs.

From a safety standpoint, risks of underdosing include inadequate treatment of anaphylaxis, further progression of an evolving allergic/anaphylactic reaction, and a potential increase in the risk of a biphasic reaction [2123]. In fact, individuals who have biphasic reactions require more epinephrine than those who experience a single phase reaction In one study of 134 patients with anaphylaxis for which data was available for 103 patients, $19.4 \%$ of these individuals had biphasic reactions. Biphasic reactors were administered less epinephrine $(p=0.048)$ and also took significantly longer to achieve

Table 2 Available epinephrine autoinjectors in Canada with current product monograph at time of publication and CSACl recommendations

\begin{tabular}{|c|c|c|c|}
\hline Brand & $\begin{array}{l}\text { Available } \\
\text { doses }(\mathrm{mg})\end{array}$ & Product monograph recommendations & CSACI recommendations \\
\hline EpiPen ${ }^{\circledR}$ & 0.30 & For those who weigh $\geq 30 \mathrm{~kg}$ & EpiPen ${ }^{\circledR}$ is recommended for those $\geq 25 \mathrm{~kg}$ \\
\hline EpiPen Jr ${ }^{\circledR}$ & 0.15 & For those who weigh between 15 and $30 \mathrm{~kg}$ & For those $<25 \mathrm{~kg}$, the EpiPen $\mathrm{Jr}^{\circledR}$ is recommended \\
\hline Allerject ${ }^{\circledR}$ & 0.30 & For those who weigh $\geq 30 \mathrm{~kg}$ & For those $\geq 25 \mathrm{~kg}$, the Allerject ${ }^{\circledR} 0.30 \mathrm{mg}$ is recommended \\
\hline Allerject ${ }^{\circledR}$ & 0.15 & For those who weigh $15-30 \mathrm{~kg}$ & For those $<25 \mathrm{~kg}$, the Allerject ${ }^{\circledR} 0.15 \mathrm{mg}$ is recommended \\
\hline Emerade $^{\mathrm{TM}}$ & 0.50 & Adult:> $60 \mathrm{~kg}: 0.3$ to $0.5 \mathrm{mg}$ depending on clinical judgement & For those $\geq 45 \mathrm{~kg}$, the Emerade $\mathrm{e}^{\mathrm{TM}} 0.5 \mathrm{mg}$ is recommended \\
\hline \multirow[t]{3}{*}{ Emerade $^{\mathrm{TM}}$} & \multirow[t]{3}{*}{0.30} & Pediatric: Children > 30 kg: 0.3 mg & \multirow{3}{*}{$\begin{array}{l}\text { For those } \geq 25 \mathrm{~kg} \text { to }<45 \mathrm{~kg} \text {, the Emerade }{ }^{\mathrm{TM}} 0.30 \mathrm{mg} \text { is } \\
\text { recommended }\end{array}$} \\
\hline & & $\begin{array}{l}\text { Adolescent }>30 \mathrm{~kg} \text { : The dosage recommendations for adult } \\
\text { patients should be followed }\end{array}$ & \\
\hline & & Adult:<60 kg: $0.3 \mathrm{mg}$ & \\
\hline
\end{tabular}


resolution of their initial symptoms compared to those who experienced a single phase reaction [23]. In addition, a large Canadian study demonstrated that the risk of uncontrolled reactions (defined as requiring 2 or more doses of epinephrine) was nearly five times higher amongst children who did not receive epinephrine in the prehospital setting [24].

\section{Are there risks associated with overdosing epinephrine?}

The risk of epinephrine overdose predominantly occurs with the administration of intravenous epinephrine [25-30]. Errors in weight-based calculations, epinephrine concentrations, and overly rapid rate of administration all contribute to adverse events observed with IV epinephrine administration. A higher risk of cardiovascular complications such as arrhythmia, ischemia, stroke, hypertension, coronary dissection and infarction have been reported with intravenous bolus epinephrine [27]. Case reports in paediatrics have reported loss of consciousness and severe pulmonary edema with accidental overdose of intravenous epinephrine [25-30].

In the adult population, a rise in troponin levels have been seen predominantly after administration of intravenous bolus epinephrine [31]. Patients with preexisting cardiovascular disease who take medications such as beta-blockers may be at higher risk of developing severe anaphylaxis. In such patients who present in acute anaphylaxis, the decision of whether to administer epinephrine and how much may pose as a therapeutic dilemma. However, the presence of cardiovascular disease does not forbid the use of epinephrine in anaphylaxis as no other medications have the life saving qualities of epinephrine in this medical emergency.

Until a wider variety of fixed doses of EAI devices becomes available, risks of excessive epinephrine doses will continue, however typically these risks are mild with intramuscular injection and are balanced by the risk of morbidity associated with lack of use. In a study of administration of $0.15 \mathrm{mg}$ via EAI versus the $0.3 \mathrm{mg}$ EAI in children between the ages of 4-8 years old and who weighed $15-30 \mathrm{~kg}$, and were at risk for anaphylaxis, children who received $0.3 \mathrm{mg}$ of IM epinephrine $(n=5)$ were found to have a higher systolic blood pressure as well as mean blood glucose compared to those who received $0.15 \mathrm{mg}$ of IM epinephrine [11]. All children experienced transient expected symptoms such as pallor, tremor, and anxiety. Those who had received EpiPen $0.3 \mathrm{mg}$ also developed palpitations, headache, and nausea, with 1 child experiencing QTc prolongation [11]. Similar transient adverse events were observed in an adult cohort of men between the ages of 18-35 years who received $0.3 \mathrm{mg}$ of intramuscular epinephrine [12].
What are the current recommendations for EAI dosing?

Currently, the CSACI advises that an EAI of $0.15 \mathrm{mg}$ be prescribed for children weighing less than $15 \mathrm{~kg}$ [7]. Similar recommendations have been made by other societies such as the WAO that advises the usage of $0.15 \mathrm{mg}$ EAI in children between the ages of $1-5$ years [3], ASCIA advising $0.15 \mathrm{mg}$ for children weighing 7.5$20 \mathrm{~kg}$ [9], EAACI advising $0.15 \mathrm{mg}$ for those weighing between 7.5 and $25 \mathrm{~kg}$ [32], and the AAAAI advising $0.15 \mathrm{mg}$ for those individuals weighing between 10 and $25 \mathrm{~kg}$ [33]. In the context of vaccine anaphylaxis, the Canadian Immunization Guide has advised that a $0.15 \mathrm{mg}$ EAI be used for those weighing up to $20 \mathrm{~kg}$, a $0.3 \mathrm{mg}$ EAI be used for those weighing between 21 and $45 \mathrm{~kg}$ and a $0.5 \mathrm{mg}$ EAI be used for those $\geq 46 \mathrm{~kg}$ [34].

For higher fixed doses of the epinephrine autoinjector, the WAO advises that $0.3 \mathrm{mg}$ should be used for children aged 6-12 years and that $0.5 \mathrm{mg}$ be used for teenagers and adults [3]. Previous Canadian consensus, EAACI, and AAAAI all advise that those who weigh $\geq 25 \mathrm{~kg}$ carry a $0.3 \mathrm{mg}$ EAI [32, 33, 35]. ASCIA and the Canadian Immunization guide outlines the use of $0.3 \mathrm{mg}$ for children and adults who are $\geq 20 \mathrm{~kg}$ indicating professional acceptance of a significantly higher proportional dose of epinephrine than $0.01 \mathrm{mg} / \mathrm{kg}[9,34]$.

\section{What does the CSACl advise on the $0.5 \mathrm{mg}$ EAI?}

The universally accepted and guideline-recommended epinephrine dose of $0.01 \mathrm{mg} / \mathrm{kg}$ itself is based on clinical experience and the ideal dose hasn't been well studied in most patient populations. Thus, discussions on optimal doses in general populations rely largely on limited evidence and professional consensus and guidelines. As weight increases above $30 \mathrm{~kg}$, the percentage of the recommended $0.01 \mathrm{mg} / \mathrm{kg}$ epinephrine dose from an existing $0.3 \mathrm{mg}$ EAI decreases resulting in potential underdosing. While it is reasonable that the dose transition can occur at $45 \mathrm{~kg}$, there are a number of key considerations.

\section{Can an EAI of $0.5 \mathrm{mg}$ be safely prescribed to patients weighing $\geq 45 \mathrm{~kg}$ ?}

While no clear data has evaluated the safety of $0.5 \mathrm{mg}$ epinephrine at this weight, extrapolations from other studies suggests that this $11 \%$ overdose is unlikely to be harmful. The CSACI recommends further study of the optimal dose.

\section{Is a dose of $0.5 \mathrm{mg}$ superior to $0.3 \mathrm{mg}$ in patients weighing $\geq 45 \mathrm{~kg}$ ?}

Head to head clinical trials comparing $0.3 \mathrm{mg}$ and $0.5 \mathrm{mg}$ for the treatment of anaphylaxis have not been published. 
However, since the universally recommended dose is $0.01 \mathrm{mg} / \mathrm{kg}$, it is reasonable to prescribe the $0.5 \mathrm{mg}$ dose in patients weighing $\geq 45 \mathrm{~kg}$. Since there is currently only one device offering this dose, the decision to use the $0.5 \mathrm{mg}$ dose may be influenced by patient preferences regarding device design and should be decided through shared-decision making. Considerations for co-morbid risk factors such as asthma, $\beta$-blocker use, body habitus, pregnancy, cardiac disease and prior severe anaphylaxis may also influence this decision. The CSACI recommends further study of the optimal treatment dose.

\section{Conclusion}

In addition to pre-existing guidelines on the transition of epinephrine autoinjector dose for children $<15 \mathrm{~kg}, \geq 15$ to $<25 \mathrm{~kg}$, and $\geq 25 \mathrm{~kg}$, we suggest that a $0.5 \mathrm{mg}$ EAI may be considered to those who are $\geq 45 \mathrm{~kg}$. Epinephrine is the first line treatment in anaphylaxis and adverse events related to a higher dose of epinephrine appear to be mild and transient in both children and adults. Through shared-decision making, some patients and clinicians may decide to use a lower dose based on patient preference for specific EAIs.

\footnotetext{
Abbreviations

EAI: Epinephrine autoinjector; CSACl: Canadian Society of Allergy and Immunology; WAO: World Allergy Organization; NIAID: National Institute of Allergy and Infectious Diseases; FAAN: Food Allergy and Anaphylaxis Network; BP: Blood pressure; mg: Milligram; kg: Kilogram; IM: Intramuscular; IV: Intravenous; ASCIA: Australasian Society of Clinical Immunology and Allergy; EAACl: European Academy of Allergy and Clinical Immunology; AAAAl: American Academy of Allergy, Asthma, and Immunology.
}

\section{Acknowledgements}

None

\section{Authors' contributions}

LDXL performed the literature search and wrote the manuscript. EMA, EL, and $\mathrm{KH}$ helped edit the final manuscript. DPM performed the literature search and edited the final manuscript. All authors read and approved the final manuscript.

\section{Funding}

None.

Availability of data and materials

Not applicable.

\section{Declarations}

Ethics approval and consent to participate

Not applicable.

\section{Consent for publication}

Not applicable.

\section{Competing interests}

LDXL has no competing interests to declare. EAM has received honoraria for speaker and moderator roles for AstraZeneca, Novartis, and GlaxoSmithKline. EL has received honoraria for being on the advisory boards of ALK-Abelló. $\mathrm{KH}$ is a voting member of the $\mathrm{NACl}$ and is on the Board of Directors of the
CSACl. She has had honorariums paid by the CSACl and BC Society of Allergy Immunology. DPM has provided consultation and speaker services for Pfizer, Aimmune, Kaleo, Merck, Covis and Pediapharm, and has been part of an advisory board for Pfizer and Bausch Health. He sits on the editorial board for the Journal of Food Allergy. He is an investigator for ALK and DBV.

\section{Author details}

${ }^{1}$ Department of Paediatrics, Division of Clinical Immunology and Allergy, University of Toronto, Toronto, ON, Canada. ${ }^{2}$ Department of Paediatrics, Section of Allergy and Clinical Immunology, University of Manitoba, Winnipeg, MB, Canada. ${ }^{3}$ Department of Paediatrics, University of Toronto, Toronto, ON, Canada. ${ }^{4}$ Department of Paediatrics, Queen's University, Kingston, ON, Canada. ${ }^{5}$ Department of Paediatrics, Division of Allergy and Immunology, University of British Columbia, Vancouver, BC, Canada. ${ }^{6}$ Department of Paediatrics, Paediatric Allergy, Asthma, and Immunology, McMaster University, Hamilton, ON, Canada. ${ }^{7}$ Halton Pediatric Allergy, Burlington, ON, Canada.

Received: 11 May 2021 Accepted: 26 November 2021

Published online: 13 December 2021

\section{References}

1. Wood RA, Camargo CA Jr, Lieberman P, Sampson HA, Schwartz LB, Zitt $M$, et al. Anaphylaxis in America: the prevalence and characteristics of anaphylaxis in the United States. J Allergy Clin Immunol. 2014;133:461-7.

2. Shaker MS, Wallace DV, Golden DBK, Oppenheimer J, Bernstein JA, Campbell RL, et al. Anaphylaxis - a 2020 practice parameter update, systematic review, and Grading of Recommendations, Assessment, Development, and Evaluation (GRADE) analysis. J Allergy Clin Immunol. 2020;45(4):1082-123.

3. Cardona V, Ansotegui IG, Ebisawa M, El-Gamal Y, Fernande Rivas M, Fineman S, et al. World allergy organization anaphylaxis guidance 2020. World Allergy Organ J. 2020;13(10):1-25.

4. Sampson HA, Muñoz-Furlong A, Campbell RL, Franklin Adkinson Jr N, Allan Bock S, Branum A, et al. Second symposium on the definition and management of anaphylaxis: summary report—second National Institute of allergy and Infectious Disease/Food Allergy and Anaphylaxis Network symposium. Ann Emerg Med. 2006;47(4):373-80.

5. Turner PJ, Campbell DE. Epidemiology of severe anaphylaxis: can we use population-based data to understand anaphylaxis? Curr Opin Allergy Clin Immunol. 2016;16(5):441-50.

6. Chime N, Riese V, Scherzer D, Perretta JS, McNamara L, Rosen M, et al. Epinephrine auto-injector versus drawn up epinephrine for anaphylaxis management: a scoping review. Pediatr Crit Care Med. 2017;18(8):764-9.

7. Halbrich M, Mack DP, Carr S, Watson W, Kim H. CSACl position statement: epinephrine auto-injectors and children $<15 \mathrm{~kg}$. Allergy Asthma Clin Immunol. 2015;11(20):1-3.

8. Sicherer $\mathrm{SH}$, Simons FER. Epinephrine for first-aid management of anaphylaxis. Pediatrics. 2017;139(3):e1-9.

9. Australasian Society of Clinical Immunology and Allergy (ASCIA). Acute management of anaphylaxis guidelines. 2020. https://www.allergy.org. au/images/ASCIA_HP_Guidelines_Acute_Management_Anaphylaxis_ 2020.pdf. Accessed 27 Mar 2020.

10. Brown JC, Simons E, Rudders SA. Epinephrine in the management of anaphylaxis. J Allergy Clin Immunol. 2020;8(4):1186-95.

11. Simons FE, Gu X, Silver NA, Simons KJ. EpiPen in young children weighing $15-30 \mathrm{~kg}$ at risk for anaphylaxis. J Allergy Clin Immunol. 2002;109(1):171-5

12. Simons FE, Gu X, Simons KJ. Epinephrine absorption in adults: intramuscular versus subcutaneous injection. J Allergy Clin Immunol. 2001;108(5):871-3.

13. Turner PJ, Patel N, Isaacs E, Duca B, Muhamed H, Nagratnam $N$ et al. American Academy of Allergy Asthma and Immunology Annual Meeting Feb 26- Mar 1 2020, Safety and pharmacokinetics of 03 mg/05 mg Epinephrine injection by autoinjector in food-allergic teenagers: a randomized, cross-over trial.

14. Kim H, Dinakar C, Mclnnis P, Rudin D, Benain X, Daley W, et al. Inadequacy of current pediatric epinephrine autoinjector needle length for use in infants and toddlers. Ann Allergy Asthma Immunol. 2017;118:719-725.e1. 
15. Kim L, Nevis IF, Tsai G, Dominic A, Potts R, Chiu J, et al. Children under 15 $\mathrm{kg}$ with food allergy may be at risk of having epinephrine auto-injectors administered into bone. Allergy Asthma Clin Immunol. 2014;10:40.

16. Bhalla MC, Gable BD, Frey JA, Reichenbach MR, Wilber ST. Predictors of epinephrine autoinjector needle length inadequacy. Am J Emerg Med. 2013;31:1671-6.

17. Song TT, Nelson MR, Chang JH, Engler RJ, Chowdhury BA. Adequacy of the epinephrine autoinjector needle length in delivering epinephrine to the intramuscular tissues. Ann Allergy Asthma Immunol. 2005:94:539-42.

18. Tsai G, Kim L, Nevis IF, Dominic A, Potts R, Chiu J, et al. Auto-injector needle length may be inadequate to deliver epinephrine intramuscularly in women with confirmed food allergy. Allergy Asthma Clin Immunol. 2014;10:39.

19. Rudders SA, Geyer BC, Banerji A, Phipatanakul W, Clark S, Camargo CA. Obesity is not a risk factor for repeat epinephrine use in the treatment of anaphylaxis. J Allergy Clin Immunol. 2012;130(5):1216-8.

20. Simons FER. First-aid treatment of anaphylaxis to food: focus on epinephrine. J Allergy Clin Immunol. 2004;113(5):P837-44.

21. Pourmand A, Robinson C, Syed W, Mazer-Amirshahi M. Biphasic anaphylaxis: a review of the literature and implications for emergency management. Am J Emerg Med. 2018;36(8):1480-5.

22. Brazil E, MacNamara AF. Not so immediate hypersensitivity: the danger of biphasic anaphylactic reactions. J Accid Emerg Med. 1998;15:252-3.

23. Ellis AK, Day JH. Incidence and characteristics of biphasic anaphylaxis: a prospective evaluation of 103 patients. Ann Allergy Asthma Immunol. 2007;98(1):64-9.

24. Gabrielli S, Clarke A, Morris J, Eisman H, Gravel J, Enarson P, et al. Evaluation of prehospital management in a canadian emergency department anaphylaxis cohort. Allergy Clin Immunol Pract. 2019;7(7):2232-8.

25. Simons FER, Chan ES, Gu XG, Simons KJ. Epinephrine for the outof-hospital (first-aid) treatment of anaphylaxis in infants: is the ampule/syringe/needle method practical? J Allergy Clin Immunol. 2001;108(6):P1040-1044.

26. Kanwar M, Irvin CB, Frank JJ, Weber K, Rosman H. Confusion about epinephrine dosing leading to iatrogenic overdose: a life-threatening problem with a potential solution. Ann Emerg Med. 2010;55(4):341-4

27. Campbell RL, Bellolio MF, Knustson BD, Bellamkonda VR, Fedko MG, Nestler DM, et al. Epinephrine in anaphylaxis: higher risk of cardiovascular complications and overdose after administration of intravenous bolus epinephrine compared with intramuscular epinephrine. J Allergy Clin Immunol Pract. 2015:3(1):76-80.

28. Callum J, Rivlin M, Carroll P. Intravenous epinephrine overdose in prehospital management of suspected anaphylaxis. BMJ Case Rep. 2020;13(1): e232654.

29. André MC, Hammer J. Life-threatening accidental intravenous epinephrine overdose in a 12-year-old boy. Pediatr Emerg Care. 2019;35(6):e110-2.

30. Liew PYL, Craven JA. Adrenaline overdose in pediatric anaphylaxis: a case report. J Med Case Rep. 2017;11(1):129.

31. Callum J, Rivlin M, Carroll P. Intravenous epinephrine overdose in prehospital management of suspected anaphylaxis. BMJ Case Rep. 2020;13: e232654

32. Muraro A, Roberts G, Worm M, Bilò MB, Brockow K, Fernández Rivas M, et al. Anaphylaxis: guidelines from the European Academy of Allergy and Clinical Immunology. Allergy. 2014;69(8):1026-45.

33. Lieberman P, Nicklas RA, Randolph C, Oppenheimer J, Bernstein D, Bernstein J, et al. Anaphylaxis - a practice parameter update. Ann Allergy Asthma Immunol. 2015;2015:341-84.

34. Anaphylaxis and other Acute Reactions following Vaccination: Canadian Immunization Guide. 2021. https://www.canada.ca/en/public-health/ services/publications/healthy-living/canadian-immunization-guide-part2-vaccine-safety/page-4-early-vaccine-reactions-including-anaphylaxis. html\#t4. Accessed 22 Mar 2021.

35. Waserman S, Chad Z, Francoeur MJ, Small P, Stark D, Vander Leek TK, et al. Management of anaphylaxis in primary care: Canadian expert consensus recommendations. Allergy. 2010;65:1082-92.

\section{Publisher's Note}

Springer Nature remains neutral with regard to jurisdictional claims in published maps and institutional affiliations.
Ready to submit your research? Choose BMC and benefit from:

- fast, convenient online submission

- thorough peer review by experienced researchers in your field

- rapid publication on acceptance

- support for research data, including large and complex data types

- gold Open Access which fosters wider collaboration and increased citations

- maximum visibility for your research: over $100 \mathrm{M}$ website views per year

At BMC, research is always in progress.

Learn more biomedcentral.com/submissions 